\title{
STRATEGIES FOR FAMILIES OF CHILDREN SERVED IN PEDIATRIC FIRST AID: THE SEARCH FOR THE CONSTRUCTION OF INTEGRALITY ${ }^{1}$
}

\author{
Fernanda Luisa Buboltz $z^{2}$ Andressa da Silveira, ${ }^{3}$ Eliane Tatsch Neves ${ }^{4}$
}

\begin{abstract}
${ }^{1}$ Paper based on the thesis - Family care actions for children attended in Pediatric Emergency Department based on their sociocultural universe, presented to the Graduate Nursing Program (PPGEnf) at Universidade Federal de Santa Maria (UFSM) in 2013.

2 M.Sc. in Nursing. Nurse at Pediatric Emergency Service, Hospital Universitário de Santa Maria (HUSM). Santa Maria, Rio Grande do Sul, Brazil. E-mail: fernandabuboltz@hotmail.com

${ }^{3}$ Doctoral student in Nursing, PPGEnf/UFSM. Assistant Professor, Curso de Graduação de Enfermagem, Universidade Federal do Pampa. Santa Maria, Rio Grande do Sul, Brazil. E-mail: andressadasilveira@gmail.com

${ }^{4}$ Ph.D. in Nursing. Adjunct Professor, Undergraduate Nursing Program and Graduate Nursing Program /UFSM. CNPq grantee. Santa Maria, Rio Grande do Sul, Brazil. E-mail: eliane.neves@ufsm.br.
\end{abstract}

\begin{abstract}
This qualitative study aimed to understand the strategies of families in the pursuit of health care for children treated in a Pediatric Emergency Department. Semi-structured interviews were held with twelve family caregivers of children attended in PED at a teaching hospital in the period March-June 2013. The data were analyzed based on the premises of content analysis. Results showed that the lack of problem-solving ability of primary care health services increases the demand for emergency care services. Relatives seek the Pediatric Emergency Department as first choice care, weaving alternative networks as a strategy to ensure quality care for their children. The restructuring of health services is recommended, based on the attributes of primary health care, overcoming the current paradigm, focused on the disease and medical consultation with one that considers comprehensive care for children and their family. DESCRIPTORS: Family. Pediatric nursing. Child health.
\end{abstract}

\section{ESTRATÉGIAS DE FAMÍLIAS DE CRIANÇAS ATENDIDAS EM PRONTO-SOCORRO PEDIÁTRICO: A BUSCA PELA CONSTRUÇÃO DA INTEGRALIDADE}

\begin{abstract}
RESUMO: Trata-se de uma pesquisa qualitativa que objetivou compreender as estratégias de famílias na busca pela assistência em saúde à criança atendida em pronto-socorro pediátrico. Desenvolveu-se a entrevista semiestruturada com doze familiares cuidadores de crianças atendidas em pronto-socorro pediátrico de um hospital de ensino no período de março a junho de 2013. Os dados foram analisados segundo os pressupostos da análise de conteúdo. Os resultados apontaram que a falta de resolutividade da atenção primária em saúde aumentam a demanda de atendimento nos serviços de urgência e emergência. Os familiares buscam o pronto-socorro pediátrico como primeira escolha de atendimento, tecendo redes alternativas como estratégia para garantir o atendimento de qualidade a seus filhos. Recomenda-se uma reestruturação dos serviços de saúde, baseada nos atributos da atenção primária em saúde, superando o paradigma atual, centrado na doença e na consulta médica, por outro que considere a integralidade do cuidado à criança e sua família. DESCRITOORES: Família. Enfermagem pediátrica. Saúde da criança.

\section{ESTRATEGIAS PARA FAMILIAS DE NIÑOS ATENDIDOS EN PEDIATRÍA DE PRIMEROS AUXILIOS: EN BUSCA DE LA CONSTRUCCIÓN DE LA INTEGRIDAD}

\begin{abstract}
RESUMEN: Se trata de un estudio cualitativo que objetivó comprender las estrategias de las familias en la búsqueda de atención de salud a los niños atendidos en un servicio de urgencias pediátricas. Desarrolló entrevistas semi-estructuradas con doce familiares cuidadores de los niños atendidos en Servicio de Urgencias Pediátricas de un hospital universitario en el periodo marzo-junio de 2013. Los datos se analizaron de acuerdo con los supuestos del análisis de contenido. Los resultados mostraron que la falta de resolutividad de los servicios sanitarios de atención primaria aumentan la demanda de la atención en los servicios de atención de emergencia y urgencia. Familiares buscan el SUP como primera opción de atención, tejiendo redes alternativas como estrategia para garantizar una atención de calidad para sus hijos. Se recomienda una reestructuración de los servicios de salud, con base en los atributos de la atención primaria de salud, superando el paradigma actual, que se centra en la enfermedad y la consulta médica, hacia un que considera una atención integral al niño y su familia. DESCRIPTORES: Familia. Enfermería Pediátrica. Salud del niño.
\end{abstract}




\section{INTRODUCTION}

The individuals' access in direct or indirect contact with the health services says a lot about the capacity of the system to correspond to their expectations and needs; to guarantee a human and social right, the right to health which, in the sphere of public policies, should reflect the respect for the multiple singularities in users' needs. ${ }^{1}$

The organization of the care delivered to the child population needs support, furthering the identification of priority actions for child health by service managers and professionals. The guidelines for the identification of integral care are based on the proper functioning of the child health services at the local level, with a view to achieving more satisfactory results for this population. ${ }^{2}$

The child is considered as a whole with multiple relations, and the family should be valued, as well as the context the child lives in. The principles like health service access and comprehensive care are highlighted at the different care levels. Facilitating the access and promoting health care, including the development of actions to prevent damage and deliver care in case of complications can improve children's health care and, consequently, their quality of life. ${ }^{2}$

Among the public child health care policies the Unified Health System (SUS) proposes, the Integrated Management Program of Prevalent Childhood Illnesses (IMCI) stands out, which incorporated the concept of integrality, proposing a child health approach at the primary care level (primary health care - PHC), systemizing clinical care and integrating curative actions with preventive and health promotion measures. ${ }^{3}$

In its guidelines, the National Primary Care Policy appoints the universal and permanent access to high-quality health services with problem-solving ability, characterizing primary care as the preferential access to the care network. This network should welcome users and promote bonding and co-accountability for care to their health needs. ${ }^{2}$

The child health care services, however, especially the primary care services, do not fully develop their attributes yet in accordance with the Ministry of Health's recommendations and, thus, do not absorb the health needs of the childhood population. These attributes are: first contact, longitudinality, integrality, coordination, focus on the family, community orientation and cultural competency. ${ }^{4}$
In view of this reality, the children's families turn to the tertiary care services to solve low and medium-complexity health problems. In a study developed in 2012 at the Pediatric Emergency Department (PED) where this research was undertaken, a care demand was appointed with $97 \%$ of primary and secondary health care actions. ${ }^{5}$

At the PED service, which receives different cases of health problems, the health professionals do not only attend to extremely severe situations that go beyond the services' problem-solving ability, but also face difficulties to constitute the health support networks needed to guarantee the users' universal access with a view to care integrality. ${ }^{6}$ Therefore, the observation rooms, for the patients' temporary stay, end up turning into inpatient units without infrastructure and human resources, interfering in the quality of care. ${ }^{6}$

In view of the challenge of constructing integrality, this study was a proposal to unveil the way the families of children attended at the PED get organized and develop actions and strategies to get care in the health/disease process.

Based on the understanding about the difficulties the child health care service users face, strategies can be outlined to improve the services at all care levels, based on the attributes of PHC.

Based on these considerations, the objective of this study was to understand the strategies of families in search of health care for children attended in pediatric first aid.

\section{METHOD}

A qualitative research was developed through a semistructured interview. The study context was the PED of a high-complexity teaching hospital belongs to the Unified Health System (SUS) of Brazil. This service receives children under health treatment at all complexity levels and is the main access route for pediatric emergency care. The service consists of a pediatrician and the nursing team, delivering care 24 hours per day.

The subjects were family caregivers of children who received care from the health team at the unit, selected based on the children's medical histories. Family caregivers of children attended at the hospital's PED were included in the study. And the family caregivers with cognitive and/or emotional limitations to participate in the interview; family members of children who died; severe cases of emergency and clinical instability; family 
caregivers who were unable to participate in the interview due to the children's demands and needs while staying at the PED were excluded.

The study participants were identified using the letter F followed by ordinal numbers, according to the order of the interviews. The data were collected between March and June 2013 and 12 interviews were held.

The analysis was developed based on the testimonies that emerged from the interviews. Hence, for this phase, the methodological proposal of thematic content analysis was followed, in the three fundamental phases of the method: pre-analysis, exploration of the material and treatment of the results. ${ }^{7}$ The categorization was obtained through the color coding of the statements, using colored pens: each color corresponded to a theme that originated the thematic categories. An analytic picture was elaborated that contained relevant information to analyze the data, based on what was obtained in the categorization of the previous phase. For each category, a picture was elaborated, containing: the subject identified with a code consisting of a letter and figure, the subject's statement belonging to the category, the analytic comment and, next, the authors who support the theoretical framework of the statement.

This study is an excerpt from the Master's thesis whose project received approval from the Ethics Committee under number: 13149613.3.0000.5346. The study complied with the recommendations of the National Health Council Resolution 466/12.

\section{RESULTS AND DISCUSSION}

The main signs and symptoms the children presented in search of care at the PED were related to upper airway infections and bronchiolitis. This emphasizes the frailty of primary health care (PHC) and of these children's access to those services, as these problems should not be attended at a pediatric emergency service. Studies appoint a certain degree of weakness of the main PHC attributes, which hampers these children's monitoring in the Family Health Strategy (FHS) and makes them return to the PED..$^{8-9}$ The family caregivers in this study figure among vulnerable populations, with an income of between one and at most four minimum wages. The research subjects were female, and mother was the predominant relationship with the children in all cases but one, which was the grandmother. Therefore, the subjects will hereinafter be called caregivers in the research results.

The research results demonstrate that the families of the children attended in the pediatric emergency department sought different alternatives for the child to receive health care. The following statements show that some of these families used private services to try and solve the children's health demands: [...] my mother is a public servant and pays [private health insurance] for my daughter (F2). [...] I paid all of the tests privately (F3).

The doctor [name of the physician] is the only pediatrician in town and he's a paid pediatrician! [...] he's the only one we can count on when needed! Then you have to pay everything! (F9).

These caregivers' statements demonstrate that they used the private health system as a strategy to seek care when the public system was unavailable. The private health care services are characterized by the activity, on their own initiative, of legally qualified independent professionals, and legal persons of private law in the promotion, protection and recovery of health. ${ }^{10}$

These caregivers paid insurances or private health care for their children, sometimes sacrificing their scarce financial resources, as the income of the families who served as subjects in the study was considered low, with contributed to enhance their precarious living conditions. ${ }^{8}$

Due to the public health service scenario, the families seek care at private services as a strategy to overcome access, coordination, longitudinality and integrality difficulties, which are essential attributes in PHC..$^{8-11}$ The families stop turning to the public services due to their lack of problem-solving ability of the children's health. ${ }^{11}$

At some time, however, these caregivers also end up turning to the public health service to solve the children's health problem as, for different reasons, they had not found sufficient support in the private care sectors: [...] it's just that [name of the private health insurance] has no pediatric emergency department. [...] her [the child's] pediatrician said [by telephone] that I should come [to the PED] because he is travelling (F2).

I called the doctor's [name of the physician] secretary! [...] When the time came [for the consultation], the secretary said there was no place [...] (F9).

[...] Then I called him [private pediatrician], I couldn't. Then my brother told me to take her to the Emergency Care Department (F12). 
The private health services also present weaknesses and are often unable to attend to their clients' needs. The statement of F2 pictures the situation of the pediatric emergency services, the place of study, as only one private health service in the city offers pediatric emergency care. Thus, when in emergency situations, the children using private medical services have the pediatric emergency department of the Unified Health System, affiliated with the university hospital, at their disposal as a resource in town. This result demonstrates that the private health service users also suffer due to the lack of structure in care.

Hence, when seeking care in public health services, the private service users are exercising their right, guaranteed by the constitutional premises of the Unified Health System (SUS). This is guided by the principle of universality, which corresponds to the guarantee of health care by the system to any and all citizens. Besides the principle of equity, in which all citizens are equal before the SUS and will be attended to as needed up to the limit of what the system can offer to all. ${ }^{10}$

Nevertheless, in view of the difficulties to get access to private and public health services, the caregivers of the children attended in the PED often ended up turning to the relatives and friends who were professionally affiliated with SUS institutions. In that sense, the caregivers looked for a facilitating strategy for the children to receive health care. The doctor said: 'take her there to the pediatric emergency department because there's a friend of mine on duty'. [...] her godmother also works here at the PED, so I trust it (F2).

You know that I got there [Primary Health Care Service], and as I am well known... I went to get a ticket early in the morning and he saw me when it was nine o'clock, then I managed them to get him a time, then it was really easy, it was really fast [care]. So, as his grandfather is a member of the municipal guard, he managed. He has already worked as a security guard at this service. It was much easier for him, if I were to go there, they would not let me see him (F4).

There was my friend who worked in health at the scheduling sector [scheduled the appointments]. And it was to the hospital [name of the institution] he [the child] went, through my cousins who are nurses [...] they used to work at this hospital [...]. I let them make the appointments, as they work there, they schedule it (F9).

These caregivers used the support networks which, in these cases, comprise the family members and friends who serve as facilitators in the search for health care. Hence, when they are confronted with difficulties to get access to the public and private services, another strategy identified was the search for the support of people who could include them on the agenda more easily, bypassing the universal access guaranteed by the SUS legislation, constituting a parallel network. Thus, the caregivers wove their own support networks, based on the daily struggle, which includes pilgrimage to different services, legal resources and the use of privileged contacts, infringing on the principles of the SUS. ${ }^{12}$

In the difficulty to solve the children's health problems, the caregivers sought alternative routes. This reality was also presented in other studies as the "Brazilian way". ${ }^{13-14}$ This represents the way used to move around socially in Brazil, in view of the rule or law that says "it cannot". In the same study, it was observed that this "Brazilian way" steps in when the public sector fails, in this case the regulation, making the line and the waiting unfeasible. $^{14}$

In addition, the caregivers were unable to solve the children's health demands during the first appointment. These women passed through different services and also returned several times to the same institution in search for a solution to the health problems. I got her [child] again and took her to the Emergency Department [municipal], on Wednesday they told me it was a mere infection. On Friday she [child's mother] called me, that she [the child] was having a fever. I left my job, I went home, I took a taxi and took her to [name of the private health service] and then they sent her here [PED] (F3).

I took him to the service [Primary Health Care Services]. Sunday he had already come here [PED]. [...] In the morning I took him to the service nearby, he [physician] forwarded me here [PED] again (F4).

I took him to the Emergency Care service, about three times, more or less! (F5).

It is highlighted that the caregivers visited other health services before reaching the PED. Some were forwarded to the service, like the cases of transfers from the Municipal Emergency Care Service, Primary Health Care Services and even private health services.

A study involving hospitalized children supported the results of this research, concluding that they visited different health services before reaching the definitive treatment. The search for care also involves the primary care services and private outpatient services. It was verified that many families of children roam between the 
primary care services and the private services in search of a solution for the health problems. ${ }^{15}$

In that sense, a lack of communication is perceived among the health support networks, which goes against the attributes of primary health care. Thus, the health services are unable to order the flows and counterflows of people, products and information among the different network components. ${ }^{4}$

In that network, the Primary Health Care Service, the Family Health Strategy, the Emergency Care Service, the Emergency Department and the private health services also suffer from the lack of structure and mainly human resources. This is clear when the pediatrician is absent from the service, as expressed in the statements: I took him to the Emergency Department, there was no pediatrician! Then I took him to the [municipal] Emergency Care Service! (F5).

There is no pediatrician there! [Primary Health Care Service] Then, in that case, we take them, then they: 'You have to take it I don't know where! You need to take a ticket first' [...] (F8).

The lack of pediatricians at the primary health care services remains one of the main limitations for the quality of child health care. There are particularities to pediatric care and the child is entitled to specialized care, which the health services should guarantee at all care levels.

In the attempt to find solutions to this bias, in 2004, the Brazilian Pediatric Society proposed the inclusion of the pediatrician in the Family Health Strategy, with a view to the high level of child and adolescent health problem solving, through care of professional quality to work in the pediatric area. ${ }^{16}$ The lack of pediatricians demonstrates a shortage in the access attribute, which considers the availability of the team to attend to the users at times beyond the health service's normal functioning hours, such as nights and weekends, mainly related to acute events. ${ }^{17}$

However, the services were unable to solve the children's health problems. The access difficulty and slow care, the absence of bonding triggered by the lack of interest and accountability, the lack of integrality and organization are identified in the health care services. ${ }^{8}$

Thus, the families in this study are not inserted in the health service as needed and, hence, have no guarantee that the health care for their children will continue. In this scenario, there is a lack of coordination that indicates the capacity to guarantee the continuity of care, through the health team, acknowledging the problems that require constant follow-up and articulated with the function of communication center of the health support networks. ${ }^{4}$

The experiences the subjects in this study reported evidence the reality of a fragmented child health care system. These strongly hegemonic systems get organized through a set of isolated care points without communication with one another and which, consequently, are incapable of delivering continuous care to the population. ${ }^{4}$ The fragmented systems are incapable of offering longitudinality and integrality and function inefficiently, ineffectively and with low quality. ${ }^{4}$

In view of the lack of care at the primary level, the families preferred seeking care at pediatric emergency care services. For the emergency services, primary health care is often unable to identify/recognize the urgency of scheduling the appointment and setting priorities. The administrative routines end up leading the users beyond the service without monitoring their trajectory in the health system, differently from the primary care recommendations. ${ }^{18}$

It is acknowledged that the children's health problems that led to the visit to the pediatric emergency department where the study was undertaken are considered as low-complexity demands and, hence, could be absorbed and solved by the FHS, which is the ideal space for child health promotion. Therefore, the need for advances is appointed in some attributes for child health promotion in the health context. Improvements are needed in the care practice, which implies reformulations in some aspects of its structure and process to offer PHC with the intended quality level. ${ }^{19}$

To change this reality, the nurses find an important space for activity in the FHS and can strengthen it to consolidate the principles of the SUS. The possibilities of this contribution to the solidification of the SUS attributes include the central role of this professional in the education and organization of nursing work in health services: the efficacy of team work; and service organization in primary health care. In addition, the nurses needed to acknowledge the range of actions they are responsible for developing in collective health, the strategic spaces it occupies in the health policy, whether in management, education, care or research. ${ }^{20}$ 
In view of this scenario, childcare is considered an important tool for full-time monitoring of child health. Childcare is focused on prevention, protection and health promotion, so that the child reaches adult life without negative influences originating in childhood. During the nursing consultation in childcare in the FHS, the nurses need to holistically attend to the child's needs, modifying the disease-centered focus. Through the consultation, monitoring, assessment and intervention in the health and disease process are possible, revealing a strong family-centered interactional and educative component. ${ }^{21}$

Thus, child growth and development should be monitored regularly, with a view to visualizing any changes early and thus provide for the necessary conducts in due time, so as to grant the children opportunities for appropriate development. The nurses are the main professionals responsible for this monitoring at the primary health care services, and should possess the knowledge needed to assess conditions that require interventions from the health services. ${ }^{22}$

Nevertheless, the low impact of the primary care services on the child health has been more frequently explained by the disarticulation among the care levels, producing a vicious circle with low problem-solving ability of the Primary Health Care Services and the Family Health Strategy. Thus, the difficulties and limitations are continuously produced and reproduced. ${ }^{23}$

Hence, to change this scenario, a health service guided by integrality is fundamental, a structuring concept of care in the SUS which should focus not only on the non-fragmented care practices, but also on the continuity of the different services necessary. ${ }^{14}$ The practice of integrality depends on the construction of new practices, based on expanded care, exercised in view of the perspective of the users' complexity and of their living conditions. ${ }^{24}$

The family should be considered as the care subject, which requires an interaction between the health team and this social unit and comprehensive knowledge about their health problems. ${ }^{4}$ Hence, the health care model presented in this study needs to be replaced by care networks, integrated systems, which intend to deliver health care in the right place, at the right time, with the right quality, right cost and with health and economic accountability for an attended population. ${ }^{4}$ Therefore, the reorientation strategy of the health model based on primary care needs to advance towards guaranteeing greater accessibility to the population and the qualification of health care. ${ }^{25}$

\section{CONCLUSION}

The findings in this study demonstrate a context in which the children's families preferred to visit the PED for care, due to the difficult access to primary health care services. That reveals a mismatch with the SUS principles and PHC attributes, mainly in terms of integrality and the child's right to health.

During the journey in search of care for the child, the relatives used strategies like the constitution of parallel networks, in the attempt to facilitate the access to health services. This artifice often makes it easier to attend to these children, but hampers the care service flows and goes against the principles of the SUS.

Another strategy the family members used related to the private services. Nevertheless, that was not a reality for all relatives as, in this study, low-income families were predominant, which makes it more difficult to use the private services.

The integration among the health services is needed, through communication among the professionals who act at the different complexity levels, i.e. by putting the health care networks in practice. The nursing team, particularly the nurse, should welcome these children and their families, in view of these users' right to receive comprehensive and high-quality care.

Therefore, to overcome the paradigm and the current scenario of child health, it is important to develop the PHC attributes as a whole, with an essential role for the nurse. The importance of the multiprofesional team is highlighted, in which each professional, within his/her legal competences at the different health care levels, is committed to the child and family members, aiming for humanized and comprehensive health care. The following limitations are highlighted: the number of subjects interviewed and the difficulty to generalize the findings. Nevertheless, these are considered points for comparison with other studies that may be developed in other regions of the country.

A restructuring of the health services is recommended, based on the attributes of primary health care, surpassing the current paradigm that is centered on the disease and the medical appointment, to another paradigm that considers the integrality of child and family care. 


\section{REFERENCES}

1. Azevedo ALM, Costa AM. The narrow entrance door of Brazil's National Health System (SUS): an evaluation of accessibility in the Family Health Strategy. Interface - Comunic Saude Educ. 2010 Out-Dez; 14(35):797-810.

2. Ministério da Saúde (BR). Secretaria de Atenção em Saúde, Departamento de Atenção Básica. Manual do instrumento de avaliação da atenção primária à saúde: Primary Care Assessment Tool PCATtool. Brasília (DF): MS; 2010.

3. Costa GD, Cotta RMM, Reis JR, Ferreira MLSM, Reis RS, Francheschini SCC. Avaliação da atenção à saúde da criança no contexto da Saúde da Família no município de Teixeiras, Minas Gerais. Ciênc Saúde Coletiva. 2011; 16(7):3229-40.

4. Mendes EV. As redes de atenção à saúde. $2^{\mathrm{a}}$ ed. Brasília (DF): Organização Pan-Americana da Saúde - Representação Brasil; 2011.

5. Arrué AM, Neves ET, Buboltz FL, Jantsch LB, Zanon BP. Demanda de um pronto-socorro pediátrico: caracterização dos atendimentos de enfermagem. Rev Enferm UFPE online [online]. 2013 Abr [acesso 2013 Dez 01]; 7(4):1090-7. Disponível em: www. revista.ufpe.br/revistaenfermagem/index.php/ revista/article/.../5899

6. Carret MLV, Fassa AG, Paniz VMV, Soares PC. Características da demanda do serviço de saúde de emergência no Sul do Brasil. Ciênc Saúde Coletiva. 2011; 16(1):1069-79.

7. Bardin L. Análise de conteúdo. $8^{\mathrm{a}}$ ed. Lisboa (PT): Geográfica Editora; 2011.

8. Silva RM, Viera CS, Toso BR, Neves ET, Rodrigues RM. Resolutividade na atenção à saúde da criança: percepção de pais e cuidadores. Acta Paul Enferm. 2013; 26(4):382-8.

9. Araujo JP, Viera CS, Toso BR, Collet N, Nassar PO. Avaliação dos atributos de orientação familiar e comunitária na saúde da criança. Acta Paul Enferm. 2014; 27(5):440-6

10. Brasil. Lei n. 8.080, de 19 de setembro de 1990: dispõe sobre as condições para a promoção, proteção e recuperação da saúde, a organização e o funcionamento dos serviços correspondentes e dá outras providências. Diário Oficial da União, 19 set 1990.

11. Oliveira BR, Viera CS, Collet N, Lima RA. Causes of hospitalization in the National Healthcare System of children aged zero to four in Brazil. Rev Bras Epidemiol. 2010; 13(2):268-77.

12. Neves ET, Silveira A. Desafios para os cuidadores familiares de crianças com necessidades especiais de saúde: contribuições da enfermagem. Rev Enferm UFPE online [online]. 2013 Mai [acesso 2013 Nov 24]; 7(5):1458-62. Disponível em: www.revista. ufpe.br/revistaenfermagem/index.php/revista/ article/.../6147

13. Damatta R. O que faz o Brasil, Brasil? Rio de Janeiro (RJ): Rocco; 2001.

14. Schimith MD, Brêtas ACP, Budó MLD, Chiesa AM, Alberti GB. Colonialismo nas relações entre trabalhadores e usuários durante as práticas de cuidado: implicações para a integralidade da atenção. Esc Anna Nery Rev Enferm. 2013 Out-Dez; 17(4):788-95.

15. Oliveira BRG, Collet N, Mello DF, Lima RAG. O itinerário terapêutico de famílias de crianças com doenças respiratórias no sistema público de saúde. Rev Latino-Am Enfermagen [online]. 2012 Mai-Jun [acesso 2013 Nov 14]; 20(3): [9telas]. Disponível em: http://www.scielo.br/pdf/rlae/v20n3/ pt_a05v20n3.pdf

16. Sociedade Brasileira de Pediatria. O Programa Saúde da Família e a pediatria [online]. Brasília (DF); 2004 [atualizado 2004 Nov-Dez [acesso 2013 Dez 06]. Disponível em: http://www.sbp.com.br/show_ item2.cfm?id_categoria=88\&id_detalhe=1451\&tipo detalhe $=\mathrm{s}$.

17. Chomatas E, Vigo A, Marty I, Hauser L, Harzheim E. Avaliação da presença e extensão dos atributos da atenção primária em Curitiba. Rev Bras Med Fam Comunidade. 2013; 8(29):294-303.

18. Barros DM, Sá MC. O processo de trabalho em saúde e a produção do cuidado em uma unidade de saúde da família: limites ao acolhimento e reflexos no serviço de emergência. Ciênc Saúde Coletiva. 2010; 15(5):2473-82.

19. Leão CDA, Caldeira AP, Oliveira MMC. Atributos da atenção primária na assistência à saúde da criança: avaliação dos cuidadores. Aspects of primary care for children: an evaluation of care-givers. Rev Bras Saúde Mater Infant. 2011; 11(3):323-34.

20. Pires RGM. Limites e possibilidades do trabalho do enfermeiro na estratégia saúde da família: em busca da autonomia. Rev Esc Enferm USP. 2011; 45(Esp2):1710-5.

21. Gauterio DP, Irala DA, Vaz MRC. Puericultura em Enfermagem: perfil e principais problemas encontrados em crianças menores de um ano. Rev Bras Enferm. 2012; 65(3):508-13.

22. Falbo BCP, Andrade RD, Furtado MCC, Mello DF. Estimulo ao desenvolvimento infantil: produção do conhecimento em enfermagem. Rev Bras Enferm. 2012; 65(1):148-54.

23. Sousa FGM, Erdmann AL, Mochel EG. Condições limitadoras para a integralidade do cuidado à criança na atenção básica de saúde. Texto Contexto Enferm. 2011; 20(Esp):263-71.

24. Mattioni FC, Budó MLD, Schimith MD. Exercício da integralidade em uma equipe da estratégia Saúde da família: saberes e práticas. Texto Contexto Enferm. 2011 Abr-Jun; 20(2):263-71. 
25. Mendes ACG, Miranda GMD, Figueiredo KEG, Duarte PO, Furtado BMASM. Acessibilidade aos ser- viços básicos de saúde: um caminho ainda a percorrer. Ciênc Saúde Coletiva. 2012 Nov; 17(11):2903-12. 